\title{
Pathophysiology of anemia in chronic kidney diseases: A review
}

\author{
Josef Zadrazil, Pavel Horak
}

\begin{abstract}
Backgroud. Anemia is one of the laboratory and clinical findings of chronic kidney diseases (CKD). The presence of anemia in patients with CKD has a wide range of clinically important consequences. Some of the symptoms that were previously attributed to reduced renal function are, in fact, a consequence of anemia. Anemia contributes to increased cardiac output, the development of left ventricular hypertrophy, angina, and congestive heart failure. According to current knowledge, anemia also contributes to the progression of CKD and is one of the factors that contribute to the high morbidity and mortality in patients with chronic renal failure and their reduced survival.

Methods. MEDLINE search was performed to collect both original and review articles addressing anemia in CKD, pathophysiology of renal anemia, erythropoiesis, erythropoietin, iron metabolism, inflammation, malnutrition, drugs, renal replacement therapy and anemia management

Conclusion. The present review summarized current knowledge in the field of the pathophysiology of renel anemia. Understanding the pathophysiology of anemia in CKD is crucial for the optimal treatment of anemia according to recent clinical practice guidelines and recommendation, and correct recognition of causes of resistence to treatment of erythropoietin stimulating agents (ESA).
\end{abstract}

Key words: anemia, chronic kidney diseases, erythropoietin, irone metabolism, erythropoiesis

Received: August 20, 2013; Accepted with revision: December 11, 2013; Available online: January 3, 2014 http://dx.doi.org/10.5507/bp.2013.093

Department of Internal Medicine III - Nephrology, Rheumatology and Endocrinology, Faculty of Medicine and Dentistry, Palacky University Olomouc, Czech Republic

Corresponding author: Josef Zadrazil, e-mail:josef.zadrazil@fnol.cz

\section{INTRODUCTION}

Anemia is one of the clinical and laboratory manifestations of CKD. It is defined as a decrease in hemoglobin $(\mathrm{HGB})<130 \mathrm{~g} / \mathrm{L}$ in men and $\mathrm{HGB}<120 \mathrm{~g} / \mathrm{L}$ in women. Relatively little is known about the development and progression of anemia in patients with CKD. As kidney function declines and in patients with more advanced CKD stages, the incidence and prevalence of anemia increased. There is an exponential relationship between decrease glomerular filtration and anemia. Typically, the development of anemia occurs when the glomerular filtration rate drops below $0.5 \mathrm{~mL} / \mathrm{s}$, or even below $0.75 \mathrm{~mL} / \mathrm{s}$ in patients affected by diabetic nephropathy. However, large differences are seen among individual patients in the degree of decline in renal function and severity of anemia. In morphological terms, anemia accompanying advanced kidney disease usually has a normocytic and normochromic pattern, and may be associated with the occurrence of acanthocytes and, possibly, schistocytes ${ }^{1,2}$.

The presence of anemia in patients with CKD has a wide range of clinically important consequences. Some of the symptoms that were previously attributed to reduced renal function are, in fact, a consequence of anemia. These include, in particular, reduced physical performance, fatigue, shortness of breath, loss of appetite, insomnia, sexual and cognitive function disorders, and reduced immunological reactivity ${ }^{3}$. Anemia contributes to increased cardiac output, the development of left ventricular hypertrophy, angina, and congestive heart failure ${ }^{4}$.
According to current knowledge, anemia also contributes to the progression of CKD and is one of the factors that contribute to the high morbidity and mortality in patients with chronic renal failure and their reduced survival ${ }^{5}$.

The present review discusses the pathophysiology of anemia in CKD. It provides details on the physiology and pathophysiology of erythropoietin and iron metabolism and briefly discusses other factors which may be important for the development of anemia (infectious processes, inflammatory conditions, certain medications, secondary hyperparathyroidism, cancer), while the importance of others is only complementary (deficiency of Vitamin $\mathrm{B}_{12}$, folic acid), or more or less hypothetical (e.g. uremic inhibitors of erythropoiesis).

\section{Insufficient erythropoietin production}

A relative lack of erythropoietin (EPO) is considered to be the main cause of the development of renal anemia. Erythropoietin is a hormone produced by specialized type I interstitial fibroblasts in the cortex and outer layer of the renal medulla. It is a crucial factor that regulates the size of the red blood cell mass related to its integration into the oxygen transport system ${ }^{6}$. The main stimulus for elevated synthesis of EPO is tissue hypoxia, which normally leads to an exponential increase in serum EPO levels ${ }^{7,8}$. This feedback is affected in patients with pathological conditions involving the kidneys and the developing anemia is not adequately compensated by a sufficient increase in the EPO production ${ }^{9,10}$. 
Endogenous EPO is a glycoprotein composed of 165 amino acids with a molecular weight of 30,400 Da. Approximately 39\% of the native molecule consists of carbohydrates. The three-dimensional structure of the EPO molecule is determined by four parallel helices, A, B, C and $\mathrm{D}$, which are interconnected by peptide chains of various lengths. The half-life of endogenous EPO is 5 hours ${ }^{11}$.

The gene that encodes EPO is located on chromosome 7 (q11-q22) ( ref. $^{12}$ ). The erythropoietin gene transcription is activated by hypoxia-induced factor (HIF-1) (ref. $\left.{ }^{13}\right)$. It is a basic protein which activates the transcription of all hypoxia-induced genes, i.e. not only erythropoietin, but also vascular endothelial growth factor, platelet derived growth factor, and the glycolytic enzymes, such as aldolase A, enolase-1, lactate dehydrogenase A, phosphofructokinase- 1 and phosphoglycerate kinase- 1 . Hypoxia-induced factor-1 is composed of two units. The HIF-1 $\alpha$ subunit is composed of 826 amino acids, whereas the HIF- $1 \beta$ subunit has two isoforms of 774 and 789 amino acids. Experimental studies have shown that with decreasing oxygen concentrations, the activity of HIF- $1 \alpha$ and HIF-1 $\beta$ in the Hela cell incubation medium increases exponentially, while under normoxic conditions, subunit HIF-1 $\alpha$ is rapidly hydroxylated and degraded ${ }^{14,15}$.

In the kidneys, which are the main source of EPO, this hormone is produced in the peritubular type I interstitial cells located in the cortex or in the outer layer of the renal medulla between the basolateral membrane of the proximal tubules and peritubular capillaries ${ }^{16,17}$. Hybridization techniques have confirmed that EPO is not produced for storage, but an increase in its production related to hypoxic stimuli is caused by exponential growth in the number of specialized cells ${ }^{18,19}$. The feedback mechanism is highly sensitive because an increase in the activity of specific mRNA can be demonstrated within two hours of the onset of hypoxic stimulus. This method of EPO regulation also allows prompt reduction in EPO production after the resolution of hypoxia ${ }^{20,21}$.

The most important extrarenal source of EPO is the liver, which accounts for $10-15 \%$ of the total EPO production $^{16}$. Hybridization techniques have demonstrated that about $80 \%$ of EPO is produced in hepatocytes and the remaining $20 \%$ in the Ito cells. Hepatocytes, in which specific mRNA was demonstrated, are located near the central vein that is known to have the lowest local oxygen tension in the liver. Ito cells have many similarities to renal fibroblasts and therefore, they are also known as perisinusoidal cells ${ }^{8}$. It is likely that the mechanism of gene expression for EPO synthesis in the liver is genetically different from the regulation of EPO production in the kidneys. Sensitivity to the hypoxic signal, in terms of the initiation of EPO production, is much lower in the liver than in the kidneys. The hepatic production of EPO may have some biological relevance only in anephric patients with severe and prolonged hypoxia and finally, in cases of hepatocellular regeneration, such as in the recovery phase after viral hepatitis ${ }^{1,10}$

The stimulatory effect of EPO on erythropoiesis is mediated by the interaction of EPO with specific receptors on the surface of hematopoietic progenitor cells in the bone marrow, called BFU-E (Burst Forming Unit Erythroid) and CFU-E (Colony Forming Unit Erythroid), which are stimulated for proliferation and differentiation. The erythropoietin receptor is a glycoprotein with 484 amino acid residues. The binding of EPO to its receptor activates the Janus kinase 2 (JAK-2), which subsequently leads to the inhibition of apoptosis of progenitor cells via multiple regulatory processes. The expression of the erythropoietin receptor is controlled during the differentiation of erythroid cells by a highly specialized transcription factor, which is called GATA-1 according to the site of binding to the DNA double helix. Targeted mutation of the GATA-1 gene was used to demonstrate the necessity of this factor for direct control of the expression of the EPO receptors on the surface EPO-sensitive erythropoietic cells ${ }^{22,23}$

CFU-E are considered to be the primary target cells of EPO. These cells are sensitive even to small amounts of EPO, and rapidly multiply in the presence of EPO, producing colonies of up to 50 erythroblasts in about 7 days. CFU-E represent about $0.1 \%$ of all nucleated cells in the bone marrow and express 300 to 1.000 receptors on the surface of their cell membrane. Under normal circumstances, the majority of CFU-E is eliminated through the mechanism of programmed cell death, but in patients with anemia, the number of cells that are not eliminated and continue in the differentiation increases due to elevated EPO levels. This mechanism allows increasing erythropoiesis quickly and as needed ${ }^{24}$. Erythropoietin receptors in the membrane of progenitor cells disappear at the basophilic normoblast stage, since more mature forms of the cells no longer need EPO for further maturation ${ }^{25}$.

\section{Iron metabolism disorders}

Iron deficiency, or its limited availability for erythropoiesis, is an important pathogenetic mechanism for the development of renal anemia. Hepcidin is currently believed to play a crucial role in the regulation of iron metabolism. This hormone was discovered by Krause in the year 2000 (ref. $^{26}$ ) and independently by Park in 2001 $\left(\right.$ ref. $^{27}$ ). Bioactive hepcidin is composed of 25 amino acids and is synthesized mainly in hepatocytes. The regulation of iron absorption and its distribution into the tissues is mediated by regulation of the expression of its receptor, ferroportin, which is known to be the sole cellular iron exporter. Hepcidin synthesis is induced by excess iron levels or inflammation, while it is inhibited by increased erythropoiesis or hypoxia. Increased hepcidin levels are known to block iron absorption from food in the intestines and its release from iron stores. The activation of erythropoiesis logically leads to the suppression of hepcidin production and subsequent mobilization of iron from its stores. Synthesis of hepcidin is stimulated by proinflammatory cytokines, in particular IL-6 (ref. ${ }^{28}$ ). However, based on current knowledge, determination of hepcidin in the diagnosis of iron deficiency in dialyzed patients is not recommended in routine clinical practice ${ }^{29}$.

Daily iron loss is small in normal individuals. Iron is lost by the desquamation of skin epithelial cells, intestinal tract mucosa, growth of hair and nails, and partly in 
the bile, sweat, and urine. The total iron loss through all these paths in adult males as measured by radioisotope techniques is 0.5 to $1.5 \mathrm{mg}$ daily. Women of childbearing potential in addition lose 30-60 mg of iron with each menstruation and $500 \mathrm{mg}$ of iron with each childbirth. Therefore, the expected daily iron loss in women is about 0.5-1 mg higher than in men ${ }^{30}$.

Under normal circumstances, physiological iron loss is fully compensated by iron reabsorption from food. In dialyzed patients, however, physiological iron loss is increased by a number of other circumstances that could easily induce iron deficiency. The main factor that leads to iron deficiency in dialyzed patients is excessive blood loss during dialysis, especially the significant amount of residual blood that remains inside the dialyzer, dialysis sets, and needles after each hemodialysis. It is generally accepted that the average annual loss of iron in dialyzed patients is $1.5-2.0 \mathrm{~g}$ (ref. ${ }^{30.31}$ ). The normal daily intake of iron is 10 to $15 \mathrm{mg}$ and the maximum absorption is about $20 \%$. Therefore, the amount of iron the body can absorb from regular food is not able to compensate for these substantial losses. Thus, dialyzed patients, who receive no iron supplementation therapy, can very easily develop a negative iron balance and depletion of tissue iron stores $^{32,33}$.

The body of a healthy adult normally contains 4-5 grams of iron. Iron deficiency is defined as a condition where the amount of iron in the body decreases to a level that is characterized by a depletion of iron stores in bone marrow, liver and spleen and imbalance between the iron supply to the tissues and the real need ${ }^{30}$. Iron deficiency is detected by laboratory methods evaluating the ratio of iron stores and available iron levels. According to the latest knowledge, examination of stainable iron in the bone marrow remains "gold standard" for determining the iron store levels in the body. Lack of iron in the body is indicated by a lack of iron in the cells of the mononuclear phagocyte system and decrease in the sideroblast count below $10 \%$ (ref. $^{34}$ ).

Under normal circumstances, storage iron accounts for approximately $30 \%$ of the body's total iron. The main places where iron is deposited are the reticuloendothelial system of the bone marrow, liver, and spleen, and the liver parenchymal cells. Iron is stored as ferritin or hemosiderin. Ferritin was first discovered by Czechoslovak physiologist Vilém Laufberger, who isolated ferritin from the spleen and liver in 1936 (ref. ${ }^{35}$ ). Ferritin is composed of an inorganic core called holoferritin, which is surrounded by a protein envelope. The protein portion of the molecule is known as apoferritin and has 24 subunits, which are designated $\mathrm{H}$ and L. Each molecule of apoferritin can bind $2.000-4.000$ atoms of iron, and the molecular weight of ferritin is approximately 500.000 $\left(\right.$ ref. $\left.^{36}\right)$. The second form of storage iron is iron stored in the form of hemosiderin. Hemosiderin granules are large aggregates of ferritin molecules with higher iron content. Hemosiderin further contains fats and, unlike ferritin, it is soluble in water. Under normal circumstances, iron is primarily stored as ferritin, and the ferritin/hemosiderin ratio is 60:40 $\left(\right.$ ref. $\left.^{31,36}\right)$.
In 1972, Addison published his observations that serum ferritin (SF) can be detected by imunoradiometric methods and he demonstrated that SF is closely related to the amount of iron in the reticuloendothelial system and is directly proportional to the releasable iron stores in the body ${ }^{37}$. The determination of SF is a relatively simple and reliable examination intended to detect reduced iron stores. When interpreting the serum ferritin concentrations, it should be remembered that SF concentrations are increased independently of the amount of iron stores in some conditions, particularly in manifest and latent infections, liver diseases, or malignant tumors ${ }^{38,39}$.

For completeness of the present overview of methods, it should be noted that determination of the urinary excretion of iron after the administration of desferioxamine or determination of the ${ }^{59} \mathrm{Fe}^{2+}$ reabsorption from the gastrointestinal tract can be used to evaluate the iron status in the body ${ }^{30}$.

To evaluate the functional iron status, we can use a variety of other laboratory parameters, such as iron plasma concentrations ( $\mathrm{pFe}$ ), transferrin, and transferrin saturation (TSAT). Low pFe levels may have many causes and in differential diagnostic terms, it is very important to differentiate low pFe levels due to actual iron deficiency from reactive hyposideremia based on utilization disorder or abnormal iron distribution, as is the case in infectious processes, tissue damage, and malignant tumors ${ }^{39}$.

Organic and ionized forms of iron are highly toxic and rather insoluble and for this reason, the transport of iron in the body is bound to a protein component, transferrin. Transferrin is a glycoprotein with a molecular weight of 79. $550 \mathrm{Da}$. The main site of transferrin production is the liver. Transferrin has two binding sites for iron, which allow the existence of apoferric, monoferric, or diferric transferrin, according to the degree of iron saturation. In addition to iron bound in the trivalent form, transferrin can, however, bind other metal ions, of which binding to aluminum may have adverse effects on the erythropoiesis in dialyzed patients (CKD 5D). In patients with sideropenic anemia, the ability of the serum to bind iron is increased, and iron deficiency is also a leading cause of elevated transferrin levels. Transferrin is known to control the internal transfer of iron from the place of absorption to the places of iron consumption or deposition, and back, when utilizing the iron released from the disintegrating red blood cells $\mathrm{s}^{40}$. Circulating iron bound to transferrin in the plasma is transported into cells via receptors expressed on the cell membranes. Binding to the receptors on the cell membrane triggers receptor-mediated endocytosis. In the acidic environment of the cell, iron is released from transferrin and after being reduced by the effects of mitochondrial ferrochelatase, it is incorporated into the heme. The final phase is exocytosis of apotransferrin back into the blood plasma. Iron deficiency results in a compensatory increase in the number of transferrin receptors and their serum concentration is also increased ${ }^{41}$.

As with $\mathrm{pFe}$, the transferrin concentrations are also influenced by a variety of clinical conditions. Transferrin levels are reduced by acute and chronic infections, malignancies, collagenosis, hemolytic anemia, or hypopro- 
teinemia ${ }^{42,43}$. Since $\mathrm{pFe}$ and transferrin are subject to numerous reactive changes under various pathological conditions, the relationship between these two values, known as TSAT, is considered to be a more accurate indicator of the metabolic status of iron. TSAT levels are calculated according to the following formula:

Transferrin saturation (TSAT) $(\%)=\frac{\mathrm{pFe}(\mu \mathrm{mol} / \mathrm{L})}{\operatorname{Transferrin}(\mu \mathrm{mol} / \mathrm{L})} \times 100$

Under physiological conditions, the binding capacity of transferrin is $20-45 \%$ saturated with iron. Decreased transferrin saturation is one of the indicators of iron deficiency. Iron is most efficiently uptaken by erythroblasts at $30-60 \%$ transferrin saturation. If the saturation exceeds $60 \%$, iron is stored in the mononuclear phagocyte system cells $^{32}$.

Diagnostic tests for functional iron status assessment are complemented by percentage of hypochromic red blood cells, erythrocyte zinc protoporphyrin testing, or serum transferrin receptor levels, which are subject to a compensatory increase in patients with iron deficiency. These tests are used much less in clinical nephrology and their validity in patients with CKD has not been characterized reliably ${ }^{30,31}$.

\section{Other factors contributing to the development of anemia}

Gradually, multiple other factors have been identified that may further exacerbate anemia developing in patients with impaired renal function. Some of these factors may be important for the development of anemia (e.g., inflammatory processes or tumors), while the meaning of others is only coincidental (e.g., folic acid or drugs), or more or less hypothetical (e.g. uremic inhibitors of erythropoiesis).

Suppression of erythropoiesis occurs during severe infectious processes, inflammatory diseases, and malignancies. Inflammation is often accompanied by malnutrition and both have a significant role in the development of anemia. We are talking about the MIA syndrome (malnutrition, inflammation, anemia). The main causes are: increased production of certain cytokines, such as IL-I, IL-6, TNF-alpha, and interferon-gamma that block the release of iron from iron stores, reduce the production of endogenous EPO, and suppress erythropoiesis. Inflammation increased uptake of the iron within cells of the reticuloendothelial system. This leads to limitation of iron availability for erythroid progenitor cells and subseguently decreased erythropoiesis. A key role in this chronic inflammation -related anemia is played by hepcidin, whose synthesis and serum levels increase up to 100 -fold during inflammation ${ }^{44}$. In the laboratory, this condition is confirmed by increased SF concentrations, and reduced pFe, transferrin levels, and TSAT (ref. ${ }^{45,46}$ ).

In patients with renal disease, reduced intravascular survival of red blood cells is caused by chronic hemolysis, which is the result of accumulation of hypothetical uremic toxins in the blood. The survival of red blood cells in patients with chronic renal failure can be normalized by the transfusion of erythrocytes from healthy people ${ }^{47}$.
The most important uremic toxins in the pathophysiology of renal anemia are polyamines, such as spermine, spermidine, putrescine, and cadaverine. Polyamines are organic cations involved in cell growth and maturation that reduce the proliferative activity of erythroid cells in the bone marrow by a direct toxic effect that is independent on their interaction with EPO (ref. ${ }^{48}$ ).

Research on uremic toxins and inhibitors of erythropoiesis is extremely challenging, as the findings obtained by individual research teams are different. For this reason, opinions on the actual relevance of uremic toxins for the development of anemia remain contradictory for a variety of reasons ${ }^{49}$. However, the work presented by A. Erslev highlighted the role of uremic toxins in the development of anemia, as the author demonstrated using precise erythrokinetic studies that the response to recombinant EPO assessed according to the daily production of red blood cells decreased by half in stabilized, adequately dialyzed patients compared to healthy persons $\mathrm{s}^{50}$.

Renal anemia may be exacerbated by a lack of folic acid or Vitamin $B_{12}$. Deficiency of Vitamin $B_{12}$ or folic acid is uncommon, occurring in less than $10 \%$ of dialyzed patients. In these cases, it usually has a macrocytic pattern. Folic acid deficiency may occur particularly in dialyzed patients, because folic acid is dialyzable. Serum folate levels are also decreased after dialysis. The loss of folic acid during the dialysis outweighs the loss of folic acid in the urine of normal people, which is about $10 \mu \mathrm{g} / 24 \mathrm{~h}$. The minimum recommended daily dose of folic acid is $50 \mu \mathrm{g}$ ( ref. $^{51,52}$ ).

A decrease in hemoglobin levels may occur in aluminum intoxication. In 1972, Alfrey described "dialysis encephalopathy" and four years later, scientists recognized its relation to aluminum intoxication ${ }^{53}$. In 1978, Elliot and Macdougall first described a decrease in hemoglobin concentrations in patients with severe aluminum intoxication $^{54}$. Osteopathy, the third main clinical manifestation of aluminum toxicity, was described in 1980 by Pierides as Vitamin D-resistant osteomalacia ${ }^{55}$. Anemia induced by the accumulation of aluminum has a microcytic and hypochromic character. Aluminum competes with iron for a binding site on the transferrin molecule, and its binding to free receptors increases, in particular in patients with iron deficiency. In addition, aluminum has been demonstrated to suppress the cytosolic uroporphyrinogen decarboxylase and mitochondrial ferrochelatase ${ }^{56}$. Worsening of anemia induced by the accumulation of aluminum is reversible and resolves after treatment with desferrioxamine ${ }^{57}$. Following the introduction of stringent standards for water purity and discontinuation of aluminum-containing phosphate binders, this phenomenon is virtually nil.

Hypoproliferative anemia may also be exacerbated by fibrous osteodystrophy, which is usually caused by severe secondary hyperparathyroidism ${ }^{58}$. Excessive parathormone levels are known to reduce EPO production, increase hemolysis, and suppress stem cells of the red blood cell line in the bone marrow ${ }^{59}$.

Anemia may be further aggravated by drugs, particularly by ACE inhibitors. ACE inhibitors suppress the synthesis of erythropoietin in a dose-dependent manner 
via enhanced oxygenation in the peritubular region due to decrease in vascular resistance in efferent arterioles, decreased serum concentration of IGF-1 and increased apoptosis of progenitor erythroid cells CD 34+ $\left(\right.$ ref. $\left.^{60,61}\right)$. Drugs are an important contributor to anemia in recipients of renal allografts. Anemia after kidney transplantation is a highly prevalent disorder affecting approximately $40 \%$ of patients and is predominantly associated with a decline of graft function. Immunossuppresants play an important additional role. Azathioprine, mycophenolate mofetil and mycophenolate sodium have a direct antiproliferative effect on bone marrow cells. Sirolimus and everolimus (mTOR inhibitors) can lead to microcytic anemia. Cyclosporine A and mTOR inhibitors are known to induce hemolytic uremic syndrome and hemolytic anemie in transplant patiens. Another immunosuppressive agent, antithymocyte globulin (ATG) can decrease hemoglobin concentration via toxic effect on bone marrow ${ }^{62}$.

An additional factor associated with anemia is malnutrition. Severe hypoalbuminemia is associated with a signifiant impairment of the erythropoietic response. A link between malnutrition and anemia can be attributed to the malnutrition-inflammation complex syndrome (MIA syndrome) ( ref. $\left.^{63}\right)$.

A working group KDIGO (Kidney Disease Improving Global Outcomes) published in August 2012 new recommendations for treating anemia in patients with CKD. The new recommendations have created many changes affecting clinical practice, in comparison to the previous American (KDOQI, 2006) and European (ERBP, 2004) ones. Newly recommended were higher serum levels of ferritin $(500 \mu \mathrm{g} / \mathrm{L})$ and for transferin saturation (30\%). Erythropoiesis stimulating agents (ESA) should be administered only following suitable supplementation of iron levels. Another important change is the lower recommended $\mathrm{Hb}$ concentration for which an intervention using ESA is indicated. ESA should be administered when $\mathrm{Hb}$ levels are in the range 90-100 $\mathrm{g} / \mathrm{L}$. In patients with symptoms of the anemic syndrome, ESA can be applied with $\mathrm{Hb} \geq 100 \mathrm{~g} / \mathrm{L}$. It is generally recommended that during maintenance ESA therapy, the $\mathrm{Hb}$ level should not exceed $120 \mathrm{~g} / \mathrm{L}$ in adult patients ${ }^{64}$. These guidelines also discussed causes of hyporesponsiveness and resistance to ESA, including iron deficiency, inflammation, malnutrition, lack of vitamin $B_{12}$ and folic acid, secondary hyperparathyreoidism, drugs and other topics concerning this importent field in clinical nephrology which are discussed in detail in this review.

\section{ACKNOWLEDGEMENT}

Author contributions: Both autors contributed equally to preparing the manuscript.

Conflict of interest statement: The authors state that there are no conflicts of interest regarding the publication of this article.

\section{REFERENCES}

1. Eschbach JW. The anemia of chronic renal failure: Pathophysiology and the effects of recombinant erythropoietin. Kidney Int 1989;35:134-48.

2. Eckardt KU. Erythropoiesis and its failure in renal dinase. Nephron 1994;67:7-23.

3. Johansen KL, Finkelstein FO, Revicki DA, Gitlin M, Evans C, Mayne TJ. Systematic review and meta-analysis of exercise tolerance and physical functioning in dialysis patients treated with erythropoiesisstimulating agents. Am J Kidney Dis 2010; 55:535-48.

4. Patel TV, Singh AL. Anemia in chronic kidney disease: new advances. Heart Fail Clin 2010; 6:347-57.

5. Suzuki M, Hada Y, Akaishi M, Hiroe M, Aonuma K, Tsubakihara Y, Akizawa T. Effect of anemia correction by erythropoiesis-stimulating agents on cardiovascular function in non-dialysis patients with chronic kidney disease. Int Heart J 2012;53:238-43.

6. Eckardt KU. Biology of erythropoietin production. Nephrol Dial Transplant 1995;10:2572-4.

7. Frede S, Freitag P, Geuting L, Konietzny R, Fandrey J. Oxygenregulated expression of the erythropoietin gene in the human renal cell line REPC. Blood 2011;117:4905-14.

8. Jelkmann W. Regulation of erythropoietin production. J Physiol 2011;589:1251-8.

9. Walle AJ, Wong GY, Clemons GK, Garcia JF, Niedermayer W. Erythropoietin - hematocrit feedback circuit in the anemia of endstage renal disease. Kidney Int 1987;31: 1205-9.

10. Nangaku M, Eckardt KU. Pathogenesis of renal anemia. Semin Nephrol 2006;26:261-8.

11. Jelkmann W. Erythropoietin after a century of research: younger than ever. Eur J Haematol 2007;78:183-205.

12. Lin F, Suggs S, Lin C, Browne JK, Smalling R, Egrie JC, Chen KK, Fox GM, Martin F, Stabinsky Z. Cloning and expression of the human erythropoietin gene. Proc Natl Acad Sci USA 1985;82:7580-7.

13. Kapitsinou PP, Liu Q, Unger TL, Rha J, Davidoff O, Keith B, Epstein JA, Moores SL, Erickson-Miller CL, Haase VH. Hepatic HIF-2 regulates erythropoietin responses to hypoxia in renal anemia. Blood 2010;116:3039-48.

14. Ratcliffe PJ, Ebert BJ, Ferguson DJP, Firth JD, Gleadle JM, Maxwell PH, Pugh CW. Regulation of the erythropoietin gene. Nephrol Dial Transplant 1995; 10:18-27.

15. Huang LE, Ho V, Arany Z, Krainc D, Galson D, Tendler D, Livingston DM, Bunn HF. Erythropoietin gene regulation depends on heme-dependent oxygen sensing and assembly of interacting transcription factors. Kidney Int 1997;51:548-52.

16. Maxwell PH, Ferguson DJP, Nicholls LG, Iredale JP, Pugh CW, Johnson MH, Ratcliffe PJ. Sites of erythropoietin production. Kidney Int 1997;51:393-401.

17. Maxwell PH, Ferguson DJP, Nicholls LG, Johnson MH, Ratcliffe PJ The interstitial response to renal injury: Fibroblast - like cells show phenotypic changes and have reduced potential for erythropoietin gene expression. Kidney Int 1997;52:715-24.

18. Lacombe C, Da Silva JL, Bruneval P. Peritubular cells are the site of erythropoietin synthesis in the murine hypoxic kidney. J Clin Invest 1988;81:620-3.

19. Koury ST, Bondurant MC, Koury MJ. Localization of erythropoietin synthesizing cells in murine kidneys by in situ hybridization. Blood 1988;71:524-7.

20. Vokurka M. Fyziologie a patofyziologie erytropoezy II: Regulace a erytropoetin. Aktuality v nefrologii 2011;17:96-102.

21. Epstein FH. Oxygen and renal metabolism. Kidney Int 1997;51:381-5.

22. Youssoufian H, Langomore G, Neumann D, Yoshimura A, Lodish HF. Structure, fuction and activation of the erythropoietin receptor. Blood 1993;81:2223-36.

23. Erslev AJ, Besarab A. Erythropoietin in the pathogenesis and treatment of the anemia of chronic renal failure. Kidney Int 1997;51:622-30.

24. Del Vecchio L, Cavalli A, Tucci B, Locatelli F. Chronic kidney disease-associated anemia: new remedies. Curr Opin Investig Drugs 2010;11:1030-8.

25. Fried W. Erythropoietin and erythropoiesis. Exp Hematol 2009;37:100715 .

26. Krause A, Neitz S, Mägert HJ, Schulz A, Forssmann WG, SchulzKnappe P, Adermann K. LEAP-1, a novel highly disulfide-bonded human peptide, exhibits antimicrobial activity. FEBS Lett 2000;480:14750 . 
27. Park CH, Valore EV, Waring AJ, Ganz T. Hepcidin, a urinary antimicrobial peptidesynthezided ion the liver. Journal of Biol Chem 2001;384:245-53.

28. Ganz T, Nemeth E. Hepcidin and Disorders in Iron Metabolism. Annu Rev Med 2011;18:347-60.

29. Tessitore N, Girelli D, Campostrini N, Bedogna V, Pietro Solero G, Castagna A, Melilli E, Mantovani W, De Matteis G, Olivieri O, Poli A, Lupo A. Hepcidin is not useful as a biomerker for iron needs in haemodialysis patients on maintenance erythropoiesis-stimulating agents Nephrol Dial Transplant 2010;25:3996-4002.

30. Cook JD, Shikne BS. Iron deficiency: Definition and diagnosis. J Intern Med 1989;226: 349-355.

31. Fishbane S, Maesaka JK. Iron Management in End-Stage Renal Disease. Am J Kidney Dis 1997;29:319-33.

32. Besarab A, Coyne DW. Iron supplementation to treat anemia in patients with chronic kidney disease. Nat Rev Nephrol 2010;6:699-710.

33. Besarab B. Anemia and iron management. Semin Dial 2011;24:498-503.

34. Zadražil J, Papajík T, Bachleda P, Budíková M, Novotný D, Ščudla V. Účast nedostatku železa na rozvoji chudokrevnosti u nemocných v pravidelném dialyzačním léčení. Vnitřní Lék 1994;40:362-6.

35. Laufberger V. Sur la cristallisation de la ferritine. Soc Chim Biol 1937; 18:1575-82.

36. Vokurka M. Fyziologie a patofyziologie erytropoezy I: Metabolizmus železa. Aktuality v nefrologii 2011;17:63-8.

37. Addison GM, Beamish MR, Hales CN, Hodgkins M, Jacobs A Liewellin P. An immunoradiometric assay for ferritin in the serum of normal subjects and patients with iron deficiency and iron overload. $\mathrm{J}$ Clin Pathol 1972;25:326-9.

38. Goldwasser P, Koutelos T, Abraham S, Avram MM. Serum ferritin, hematocrit and mean corpuscular volume in hemodialysis. Nephron 1994;67:30-5

39. Ford BA, Coyne DW, Eby CS, Scott MG. Variability of ferritin measurements in chronic kidney disease; implications for iron management. Kidney Int 2009;75:104-10.

40. Gkouvatsos K, Papanikolaou G, Pantopoulos K. Regulation of iron transport and the role of transferrin. Biochim Biophys Acta 2012;1820:188-202.

41. Luck AN, Mason AB. Transferrin-mediated cellular iron delivery. Curr Top Membr 2012;69:3-35.

42. Wessling-Resnick M. Iron homeostasis and the inflammatory response. Annu Rev Nutr 2010;30:105-22.

43. Roy CN. Anemia of inflammation. Hematology Am Soc Hematol Educ Program 2010;2010:276-80.

44. De Lima GA, Mazzali M, Gentil AF, Plotegher L, Grotto HZ. Anemia in chronic renal disease: evaluation of inflammatory activity on erythropoiesis and iron metabolism in patients not submitted to dialysis treatment. Clin Lab 2012;58:695-704.

45. Rambod M, Kovesdy CP, Kalantar-Zadeh K. Combined high serum ferritin and low iron saturation in hemodialysis patients: the role of inflammation. Clin J Am Soc Nephrol 2008;3:1691-701.

46. Cooper AC, Mikhail A, Lethbridge MW, Kemeny DM, MacDougall IC. Increased expression of erythropoiesis inhibiting cytokines (IFN- $\gamma$,
TNF- $\alpha$, IL-10 and IL-13) by T cells in patients exhibiting a poor response to erythropoietin therapy. J Am Soc Nephrol 2003;14:1776-84

47. Wallner SF, Vantrin RM. Evidence that inhibition of erythropoiesis is important in the anemia of chronic renal failure. J Lab Clin Med 1981;97:170-8.

48. Kushner D, Beckman B, Nquyen L, Chen S, Della Santina C, Husserl F, Rice J, Fisher JW. Polyamines in the anemia of end-stage renal disease. Kidney Int 1991;31:725-32.

49. Brunati C, Cappellini MD, De Feo T, Guastoni C, Ballerini L, Busnach G, Civati G, Fiorelli G, Minetti L. Uremic inhibitor of erythropoiesis. A study during treatment with recombinant human erythropoietin. Am J Nephrol 1992;12:9-13.

50. Erslev AJ, Besarab A. The rate and control of baseline red cell production in hematologically stable patients with uremia. J Lab Clin Med 1995; 126:283-6.

51. Teschner M, Kosch M, Schaefer RM. Folate metabolism in renal failure. Nephrol Dial Transplant 2002;17:24-7.

52. Elliott J, Mishler D, Agarwal R. Hyporesponsiveness to erythropoietin: causes and management. Adv Chronic Kidney Dis 2010;17:94-100.

53. Alfrey AC, Legendre GR, Kaehny WD. The dialysis encephalopathy syndrome. Possible aluminium intoxication. N Engl J Med 1976;294:184-8.

54. Elliot HL, MacDougall AJ. Aluminium studies in dialysis encephalopathy. Proc Eur Dial Transplant Assoc 1978;15:157-63.

55. Pierides AM. Haemodialysis osteodystrophy with osteomalacia as the main finding-relation to aluminium intoxication. Clacif Tissue Res 1980;31:453-65.

56. Schwartz R, Dombrouski J, Kluin K. Microcytic anemia and aluminium toxicity. Kidney Int 1985;27:128-33.

57. Altmann P, Plowman D, Marsh F, Cunningham J. Aluminium chelatation therapy in dialysis patiens: Evidence for inhibition of hemoglobin synthesis by low levels of aluminium. Lancet 1988;1:1012-15.

58. Bhadada SK, Bhansali A, Ahluwalia J, Chanukya GV, Behera A, Dutta P. Anemia and marrow fibrosis in patinets with primary hyperparathyreoidism before and after curative parathyreoidectomy. Clin Endocrinol 2009;70:527-32.

59. Limrick C, McNichols-Thomas C. Anaemia and mineral bone disorder in chronic kidney disease: a review of the current literature and implication for clinical nursing practice. J Ren Care 2009;35:94-100.

60. Hess E, Sperschneider H, Stein G. Do ACE inhibitors influence the dose of human recombinant erythropoietin in dialysis patients? Nephrol Dial Transplant 1996;11:749-51.

61. Vlahakos DV, Marathias KP, Madias NE. The role of the renin-angiotensin system in the regulation of erythropoiesis. Am J Kidney Dis 2010;56:558-65.

62. Malyszko J., Oberbauer R., Watschinger B. Anemia and erythrocytosis in patient after kidney transplatnation. Transplant Int 2012;25:1013-23

63. Gaweda AE, Goldsmith LJ, Brier ME. Aronoff GR. Iron, inflammation, dialysis adequacy, nutritional status, and hyperparathyreodism modify erythropoietic response. Clin J Am Soc Nephrol 2010;5:576-81.

64. KDIGO Clinical Practice for Anemia in Chronic Kidney Disease. Kidney Int 2012, 2 (Suppl 4):279-366. 